\title{
Social Complexity, Inner Asia, and Pastoral Nomadism*
}

\author{
Nikolay N. Kradin \\ Institute of History, Archaeology and Ethnology, \\ Far-Eastern Branch of the Russian Academy of Sciences, \\ Vladivostok; Institute of Mongolian, Buddhist, and Tibetan \\ Studies, Siberian Branch of the Russian Academy of Sci- \\ ences, Ulan-Ude
}

\begin{abstract}
For many years scholars have interpreted the large polities of pastoral nomads of Inner Asia as having different levels of complexity (pre-state, early state, feudal society, nomadic civilization, etc.). The present article discusses the debates of recent decades within the post-Marxist and postmodern approaches as well as the polemics about the relation between internal and external factors, about the hierarchy and heterarchy, periodization and complexity levels. Many important issues give rise to a new wave of debates. However, there is still no consensus on a number of fundamental issues. We call to a new phase in nomadic studies (nomadology) - the transition from the great theories to the middle-range theories. We also give comments on some articles of the present special section.
\end{abstract}

\section{INTRODUCTION}

'Pastoral nomads have had a persistent fascination for anthropologists,' states one of the popular reviews of ethnography of nomadism (DysonHudson R. and Dyson-Hudson N. 1980: 15) and this statement is, in fact, difficult to disagree with. Herodotus and Sima Qian, pioneers of history, savored every specific detail of the nomadic world that was so alien to them. It simultaneously attracted and scared them. The same feelings were known to the later explorers of this 'mysterious' part of the world. 
Centaur, a mysterious creature, half-human, half-horse, became a meme of the steppe civilization.

The factors leading to the creation of the largest nomadic polities, known to scholars as nomadic empires, as well as the specific features of their social structure are key issues in the study of nomadism. In essence, this issue concerns the specific aspects of how 'a state' originated among the nomadic pastoralists. These problems have been discussed by scholars for quite a while. In fact, it was in the nineteenth century that the issues of whether the nomads were able to build statehood and whether any differences existed between political organizations of nomads and sedentary peoples were raised. Philosophers from Voltaire to Hegel denied the nomads possessed the ability to create statehood. However, opinions among historians and ethnographers were divided: some of them believed that the nomads kept maintaining a tribal organization, others advocated for the recognition of wealth disparity and authority in nomadic societies. In the nineteenth century, the so-called conquest theory of state formation emerged. According to it, one of the options for the formation of the state presupposed the nomadic conquest of sedentary peoples.

In the twentieth century, this topic was actively discussed in Soviet Marxist history, and anthropology in the course of the so-called discussion of nomadic feudalism. The historiography of this discussion has been discussed in numerous studies. It has been considered in more detail in a whole series of special studies (Kogan 1980; Khalil 1983; Popov 1986; Gellner 1988; Markov 1989, 1998, 2001; Kradin 1992; Masanov 1995; Vasyutin and Dashkovsky 2009, etc.). One can distinguish three large stages within the discussion: 1) the first period (the 1920s - early 1930s) was characterized by relative freedom to choose various approaches from the denial of class differentiation among nomadic societies to the recognition of tribal state and classes among the nomads; 2 ) the second period (1934 - the mid1960s) was the time when the theory of nomadic feudalism dominated the field from the moment of its creation to the discussion of patriarchalfeudal relationships; and 3) the third period (the mid-1960s - early 1990s) - from the moment of revival of the discussion on the Asiatic mode of production to the end of the Soviet era. This period is characterized by the development of new approaches and substantiated critique of the nomadic feudalism theory (Kradin 1992, 2007).

This paper will survey the current state of the discussion on the nature of nomadic polities and the origin of complex societies and empires among the nomads. For this purpose, I will assess modern influential trends. I will turn to the most interesting studies in contemporary nomadic studies or nomadology. Only a limited number of authors cited in this paper will be referenced. Nowadays, publication activity is extremely 
high and each researcher has at least several publications on each issue. I am familiar with most of these studies. However, for space-saving reasons, I will cite only the most significant or the most prominent of them.

\section{FROM MARXISM TO EMPIRICISM}

It can be said that by the end of the Soviet era four main viewpoints on the nature of nomadic social structure had formed in Russian nomadology (see in more detail: Kradin 1992, 2003, 2007, 2014; Vasyutin and Dashkovsky 2009): (1) pre-class society among the nomads. At the same time, some researchers believed that nomads could achieve statehood with the establishment of foreign exploitative relations; (2) the early state of the nomads; (3) feudalism among the nomads: a) the orthodox version of the nomadic feudalism theory; b) the saun version of nomadic feudalism; c) power over the nomads as the basis of feudalism; the formation of feudalism in the course of poor nomads sedentarization; and d) opinions about the feudal essence of nomadism without indicating its nature; and (4) a special nomadic or exopolitary mode of production.

Unfortunately, theoretical research in nomadology became unpopular in the post-Soviet period. In a broader context, one can state that a wave of empiricism has swept through historical studies, archaeology, and anthropology. A huge number of studies introducing empirical material into scientific circulation is published each year. Sometimes, there are interesting generalizations that can be attributed to the middle-range theories. However, the number of conceptual generalizing studies by the Russianspeaking researchers is exceedingly small. One of the primary reasons might be the disillusionment of scholars in Marxism and, subsequently, their unwillingness to create new idols for themselves. It is possible that this fact can be explained by the general crisis in academic studies, endless reformatting of the structure of research studies, poor funding, and fierce competition for additional resources.

One way or another, in the first post-Marxist decade the discussion was rather sluggish and the leadership gradually shifted to foreign researchers. The very focus of discussion also changed. The most relevant issue was the level of complexity the nomadic empires corresponded to. Some authors support the idea of the pre-state nature of nomadic societies (Kradin 1992, 2002; Skrynnikova 1997; Kradin and Skrynnikova 2006, etc.). Others write about the early state among the nomads (Trepavlov 1993; Klyashtorny and Savinov 1994; Kychanov 1997, 2010; Klyashtorny and Sultanov 2000; Klyashtorny 2012; Tishin 2015, etc.). A certain controversy was stirred up by the question: what is the basis of nomadism's specificity? Is it the inner essence of pastoralism, the basis of the socalled nomadic mode of production (Masanov 1995; Kalinovskaya 1996; Markov 1998), or the peculiar features of external adaptation of exopoli- 
tarian or xenocratic nomadic empires to agricultural civilizations (Kradin 1992, 2002, etc.).

At the same time, new methodological approaches, such as the theory of chiefdom and early state, the civilizational approach, world-systems analysis, global history, began to be actively introduced into Russian humanities. Their use in nomadology has already yielded certain results (Koryakova 1996; Kradin, Bondarenko, and Barfield 2003; Bazarov, Kradin, and Skrynnikova 2004-2008; Koryakova and Epimakhov 2007; Vasyutin and Dashkovsky 2009; Vasyutin 2010, 2011a, 2017; Vdovichenkov 2016, 2018; Petrov 2016, etc.). Foreign researchers joined the discussion of such definitions as nomadic empire (Kradin 1996, 2000; Vasyutin 2010; Pikov 2010; Rogers 2012) and super-complex chiefdom (Maekawa 2006; Scheidel 2010, 2011; Di Cosmo 2011; Shiraishi 2015; Kim 2017).

To overcome the formed monism in 1991 the publication appeared which made attempts to view nomadism from the civilizational approach viewpoint (Burovsky 1995; Enkhtuvshin 2003; Pikov 2009). My critical argument in this regard remains unchanged: the term civilization is very polysemantic and to avoid confusion it would be useful to leave it to describe local civilizations (cultures, nations, etc.). Meanwhile, the problem of identifying the so-called habitus of nomadic civilization remains unsolvable. Nomadism is something different. Nomads and pastoralists never thought of themselves as a single entity opposed to all others. A Hyksos and Hun, a medieval Arab or Mongol, a Nuer from Sudan and an Arctic reindeer herder were related not only to different peoples but belonged to different cultural spaces. That said, some nomadic societies could form the core of an existing civilization (for example, Arabs), while others could be a part of the barbaric periphery of some civilization (Hyksos prior to the conquest of Egypt), still others stayed practically outside the civilization processes up until the beginning of the colonial period (the $\mathrm{Nu}-$ er, Chukchi) (Kradin 2018a).

For this reason, it seems more promising to consider separate and large ethnocultural nomadic entities localized in certain geographical zones within the framework of the civilizational approach. From this viewpoint, the Arabian Peninsula was such a habitat. It was there that the Arab civilization originated. It is possible to speak about Inner Asia as a general civilization (Perlee 1978). For the latter the features such as division into wings, the decimal system, ideas about power, enthronization rituals, love of the horse and camel races, a peculiar worldview were singled out. The issue of Mongolian civilization should be viewed in the same vain (Zheleznyakov 2016, etc.). A particularly debatable issue in recent times is whether it is legitimate to single out a particular Golden Horde civilization (Kulpin 2004, 2008; Kramarovsky 2005; Mirgaliev 2014, etc.). The term has already so firmly established itself in the academic community 
that a whole academic journal of the same name was published. However, it is important to stop in time: identification of more and more new nomadic civilizations cannot be limitless. On the one hand, the number of civilizations cannot be equal to the number of ethnic entities. It is important not to go too far in this. On the other hand, each singled out civilization should have a corresponding set of specific distinguishing features the so-called habitus of civilization.

\section{FRENCH STRUCTURAL MARXISM}

Back in the last third of the twentieth century the French Marxist anthropologists advocated a particular point of view on the essence of nomadic societies. From the positions of structural Marxism, they developed a concept of a specific nomadic formation based on internal stratification, which, in its turn, was based on private ownership of livestock. They emphasized the egalitarian and segmental nature of nomadic society, the lack of division between basis and superstructure in pastoral communities, which was expressed in the interweaving of economic, kindred, religious, and other relations. Under the nomadic mode of production, they understood a complex unity of environmental, economic, and sociocultural components. At the same time, Karl Marx's German mode of production occupied an important place in the concept (Bradburd 1984; Digard 1989; Bonte 1981, 1990).

Theoretical studies by Jacques Legrand (2011) occupy a particular place among the French scholars. His central idea is the structuralist interpretation of nomadic societies within the sedentarism - nomadism dichotomy. If sedentary societies are characterized by broadly understood accumulation and stable existence, for nomads the limited resource base, instability, and cyclical fluctuations are the key factors of their existence. The nomads' dispersed mode of existence and their constant seasonal roaming with livestock form the core of this system. Such characteristics appear unusual for sedentary residents as they repel and frighten them. It is exactly this reason that makes them perceive nomads in a negative light.

Both systems are intertwined. Legrand views such relations in terms of symmetry-asymmetry. For the sedentary peoples exchanges with other societies are primarily of market nature and they are subordinate to the same accumulation goal. For the steppe dwellers non-economic exchange and acquisition of such goods, which are impossible to produce while living a nomadic lifestyle, are more important.

It is difficult to trace the logic of the nomadic world using the terms of sedentary society. Hence, there appear different ideas of the border. For farmers and urban dwellers, it is a barrier separating them from the aliens, their potential enemies. For the nomads, it is a zone of interaction with the world around them. For instance, contacts and exchanges with neighbor- 
ing settled peoples shift into the sphere of politics. Trade is related to plunder and war, which may become a regular activity (a sort of onesided exchange), though more often they are a method of coercion to open or resume exchanges.

\section{THE ROLE OF INTERNAL AND EXTERNAL FACTORS}

The discussion about the correlation between internal and external factors of nomadic societies' development attracted much attention in Western nomadology. The proponents of the first viewpoint (the autonomy theory) assume that the nomads could come to the statehood independently, while their opponents (the external dependency theory) argue that the nomads did not need statehood and the emergence of nomadic empires was mediated by the nature of the relationship with neighboring urban societies.

Particularly, in recent years Nicola Di Cosmo has contributed a lot to the argumentation of the autonomy theory. In his opinion, the concept of the origin of the steppe empires based on the assumption that the pastoral economy was limited, was itself erroneous from the very outset, because the nomads to a certain extent were familiar with agriculture (Di Cosmo 1999: 12, note 38). At the same time, it would be wrong to view the emergence of nomadic empires as an evolutionary process. Rather, it was a process of gradual cumulative gain of political experience (Ibid.: 38). The point of departure is the structural crisis within the tribal society. This crisis resulted in the militarization of the steppe society, the creation of permanent military units and special squads, and the strengthening of the authority of military leaders. With the advent of a charismatic leader, the preconditions for the genesis of statehood were formed. Centralization of power led to territorial expansion and growth of revenue, as well as the emergence of a government apparatus (Di Cosmo 1999: 15-26, 167-186).

The studies by William Honeychurch belong to the same paradigm. He assumes that the nomads could create organizationally sophisticated polities based on internal integration. Their internal structure was the same as that of the settled agricultural states. Nomadic states and empires have complex economic systems, specialized crafts, and urbanization. In this sense, similar life principles were characteristic of both the nomads and sedentary dwellers. For years, the author carried out archaeological research in Mongolia and came to the conclusion that the life-sustaining system of the ancient nomads did not depend on external resources (Honeychurch 2013, 2014, 2015, 2017).

The dependence theory goes back to the seminal book by Owen Lattimore on cultural ecology and adaptation of nomads near the Chinese frontier (Lattimore 1940). Lattimore showed the dependence of the nomads on the natural environment and neighboring settled agricultural so- 
cieties. In his opinion, this determined social organization and caused the prevalence of cyclical over evolutionary trends in the steppe world.

These ideas were further developed in studies by other researchers. Anatoly Khazanov showed that the internal ecological and economic adaptation of the nomads was far from complete. It was complemented by the adaptation of nomadism to the outside world, which could be realized in various strategies - from ordinary trade to extortion of tribute from agriculturalists or conquest of sedentary societies (Khazanov 1984). These conclusions overlap with the research results obtained by S. Jagchid, according to whom it was hard for nomads to exist without the produce of settled societies. Since the agricultural economy was more stable, they had no particular stimuli to trade with the nomads. Therefore, the main reasons for wars between the nomads and the agriculturalists were economic. The nomads sought to wage wars without absorbing enemy territories (Jagchid and Symons 1989; Jagchid 1991).

According to Peter Golden, there is not a single nomadic state that could have emerged as a result of internal factors (Golden 1991: 136138). The nomads' mobility gave them a strong military advantage, but, simultaneously, was a potential factor for separatism. An external catalyst produced by the necessity to gain access to the produce of the agriculturalurban society played the main role in the formation of a state. Moreover, it was not characteristic for the nomads of Western Eurasia to form statehood except for those cases where they conquered an agricultural society and resettled to its territory. In Eastern Eurasia, their empires were more in line with the level of early states, albeit a strong role for kinship institutes, the preservation of tribal institutes, the universal armament of the people, and mobility of population and resources (Golden 1992, 2001, 2011, 2015).

A number of studies from the late twentieth century display an opinion that ideology was fundamentally important in the formation of the nomadic empires. Kürsat-Ahlers (1994) notes that given the unstable pastoral economy the accumulation of surplus product was limited. Therefore, the formation of political institutions should have been based on other principles. In her opinion, in the case of steppe societies, the most important factor was the monopoly of the chieftains on the ritual sphere, forming of war cults, worship of Heaven and ancestors.

According to Isenbuke Togan, since the wealth of pastoralists was ephemeral due to the constantly looming threat of zud (snow storm) or fodder shortage, property inequality could not play a significant role. Ideology manifested in the concept of Heaven (Tenggri) and the sacred charisma (qut) were at the core of the social structure. Redistribution was important for the consolidation of tribes. Social and political institutions of the nomads were flexible. A pyramid-shaped segmental lineage system 
was at the basis of the society. From time to time some clans took the leading positions only to be later replaced by others. An egalitarian social structure was periodically replaced by a centralized imperial hierarchy. Usually, after some time, centrifugal forces worked and tribalization ensued, leading to the autonomy of the parts of the empire. It was followed by detribalization with the strengthening of military institutions and shaping of universal ideological concepts. Next, the mechanisms of retribalization were engaged and the cycle repeated once again (Togan 1998).

\section{PERIODIZATION AND LEVELS OF COMPLEXITY}

It should be noted that a division into so-called early and late nomads was formed within Soviet archaeology. The origins of this periodization trace back to the scheme of the five modes of production, that is, to the division into ancient and medieval periods. That said, the so-called early nomads (before the middle of the first millennium AD) are usually viewed as prestate or slave-owning, and later - early class or early feudal societies (Griaznov 1939). The formation of the mature feudal society took place in the period of late nomads, during the Middle Ages. In foreign literature, this issue was considered somewhat differently. The periodization of the Japanese historian Jitsuzo Tamura was fundamentally important. He singled out two large cycles in the history of Northern Eurasia: (1) the cycle of the ancient nomadic empires of the arid zone of Inner Asia (the second century $\mathrm{BC}$ - the ninth century $\mathrm{AD}$ ): Xiongnu, Xianbei, Rouran, Turks, and Uighurs; and (2) the cycle of medieval conqueror dynasties originating in the taiga (Jurchen, Manchu) or steppe (Khitan, Mongols) zones (the tenth - early twentieth centuries): Liao, Jin, Yuan, and Qing. The societies of the first cycle interacted with China remotely, while the states of the second cycle conquered the agricultural South and created symbiotic state structures (Tamura 1956).

Among modern periodizations, one should specifically mention the scheme created by Japanese archaeologist Noriyuki Shiraishi who views the evolution of the nomadic empires within a spiral evolution from the state of fragmentation to the phase of centralization and, finally, to gradual decentralization. Meanwhile, each turn of the spiral from the Xiongnu to the Mongols is characterized by an ever-widening expansion of the arc of power, reaching its maximum span in the thirteenth century (Shiraishi 2001, 2002).

The viewpoint of Nicola Di Cosmo is very popular. Based on the method of generating income from the outer world he singled out four stages in the history of the region: 1) the period of tributary empires, from the Xiongnu to the Rouran (209 BC - 551 AD); 2) the period of the tradetributary empires of the Turks, Khazars, and Uighurs (551-907 AD), when the nomads learned to gain profit from foreign exchange; 3) the period 
of dual-administrative empires (907-1259 AD) when the nomads learned to conquer agricultural civilizations (Khitans, Jurchens, and Mongols before Khubilai); and 4) the period of the mature empires (1260-1796), which, alongside with other methods of exploitation, used direct taxation (Mongols and their West Asian successors, Manchus) (Di Cosmo 1999).

Perhaps, the most elegant model was proposed by Thomas Barfield. It captures the synchronization of the processes of rising and decline of nomadic empires and similar processes in China. The Han Empire and the Xiongnu state appeared during the same decade. The Turk Khaganate emerged exactly at the time when China was unified under the power of the Sui and, later, Tan dynasty. When China plunged into internal trouble and economic crisis the system of remote exploitation by the nomads ceased to work and the imperial confederation split into separate tribes until peace and order were restored in the south. In Barfield's view, such cyclic structure of political relations between the peoples of China, Central Asia, and the Far East, was repeated three times within two millennia: from the Xiongnu to the Rouran, from the Turks to the fall of the Yuan dynasty, and from the Ming period to the Xinhai Revolution, which ended this cyclical evolution (Barfield 1992). Barfield calls the nomadic empires shadow because in a way they were in the shadow of agricultural civilizations (this term also suits well because it highlights the shadow character of the economy of the steppe empires). He singles out several variants of shadow empires: 1) mirror - which appeared as an 'answer' to the pressure from the sedentary-agricultural empires (Xiongnu, Turks, etc.); 2) maritime trade empires (Phoenicia, Crete); 3) predatory empires created by marginal groups after the collapse of the central society (Nubia, peoples of the Manchurian frontier - Liao, Jin, and Qing). There is one more model in the classification - nostalgic empires - emerging on the ruins of large empires of the past (states of the fourth - the sixth and the tenth - the twelfth centuries in China, Carolingians in Europe). However, the imperial nature and secondary (shadow) character of the economy of the societies used as examples is doubtful (Barfield 2001).

The concept has been widely criticized by scholars in oriental studies. A number of researchers wrote that Barfield exaggerated the role of external factors. They considered internal causes to be more important for the creation of an empire (Di Cosmo 1999, 2002; Scheidel 2011). He was accused of incorrect sampling ('a model with three examples and two exceptions') (Wright 1995: 307), and researchers also pointed to the lack of a strict correlation between the rhythms of the rise and decline of China and the nomadic empires. In particular, the history of the formation of the First and Second Turk Khaganates does not fit into the synchronous model of cycles between the nomadic empires and China (Drompp 2005: 109; cf. Vasyutin 2011b). 
Barfield's ideas were further developed in the elegant 'feedback loop' model proposed by Peter Turchin (2009). Its essence lies in the fact that nomads and agriculturalists influenced each other for quite a long time. Raids of nomads suggested centralization of farmers, which, in turn, required unification of the steppe dwellers into larger entities. In this way, the "initial "anisotropy" (i.e., the heterogeneity of the medium's properties - N.K.) in military power on the agricultural-steppe frontier establishes an autocatalytic process resulting in an uncontrolled increase in the size of polities on both size of the border' (Ibid. 2009: 197). The model provoked a feedback round of discussion (Di Cosmo 2011: 43; Scheidel 2011: 117-119).

The path from the formation of nomadism to the creation of nomadic empires stretched for more than a thousand years. Lyudmila Koryakova $(1996,2002)$ argues that it is possible to point out several waves of complex societies' formation in Eurasia in the Bronze and Early Iron Age. The first wave (up to $1600 \mathrm{BC}$ ) was the era of chariots, the time of theocratic chiefdoms and tribal confederations (Sintashta, Petrovka). The second wave (1600-500 BC) was the era of pastoral societies, the time of simple chiefdoms (Andronovo, Fedorovo). The third wave (from 500 BC) was the formation of nomadism. It was the time of complex chiefdoms and nomadic empires (Arzhan, Xiongnu).

Barfield identified four complexity levels of nomadic pastoralists, which do not contradict the above periodization: 1) acephalous societies, represented by, for example, pastoralists of Africa; 2) tribal communities numbering tens of thousands of people led by informal leaders; 3) supratribal confederations numbering a hundred or more thousand people; and 4) centralized imperial confederations numbering up to one million people (Barfield 1993, 2003). He nevertheless advocates, against use of the term evolution because linear development of nomads is untraceable, and there are only periodic leaps from fairly simple political systems to gigantic empires.

Yet, Barfield (2003) agrees that there are certain limits to the increasing complexity of steppe societies. At the same time in his studies, he describes two models of nomadic societies. The first is applied to the nomads of Eurasia where kinship genealogy was highly important for the formation of the supra-tribal hierarchy. Due to this reason, the factor of religion did not play an important role. The second model was characteristic of North African and Middle Eastern pastoralists. An egalitarian social organization existed here. Islam was very important in the formation of supra-tribal unity (Idem 1995).

A cross-cultural analysis of 15 pastoral and nomadic societies confirms his conclusions. Indeed, it is possible to distinguish approximately three to four levels of cultural (and political) complexity of the nomadic societies. 
The simplest are segmental acephalous societies without governing bodies. The next stage is that of so-called secondary tribes, tribal confederations, and simple chiefdoms. The latter are represented on a large scale among nomadic empires, as well as smaller quasi-imperial polities (such as the Tatar khanates after the collapse of the Golden Horde), and independent or semi-dependent khanates (Kazakh and Kalmyk khanates, etc.) of the Early Modern period (Kradin 2006).

\section{HETERARCHY AND HIERARCHY}

In recent decades many scholars have written about two different strategies in the process of cultural evolution. The first one, the hierarchy or network strategy is based on the power hierarchy and centralization. It is characterized by the concentration of wealth among the elite, the presence of dependence and patronage networks, the reflection of social differentiation in funerary rituals, the elite's control over trade in luxury goods, the development of crafts for the needs of the upper classes, the presence of the cults of chieftains and their ancestors, and the reflection of status and hierarchy in the ideological system and architecture. The second one, or the heterarchy or corporate strategy, is characterized by a larger distribution of wealth and authority, more moderate accumulation, segmental social organization, economic efforts of the society aimed at the achievement of common goals (such as food production, building fortifications, temples, and so on), an universalizing cosmology, and religious cults and rituals. The architecture reflects the standardized lifestyle.

Approximately at the same time, albeit on different historical materials and using different terminology, this same approach was developed for materials from Middle East, Central and Inner Asia, the Caucasus, Western Europe, and the New World (Berezkin 1995, 2000; Korotayev 1995; Crumley 1995, 2001; Blanton et al. 1996; Bondarenko and Korotayev 2000; Kradin et al. 2000; Haas 2001; Grinin et al. 2004; Bondarenko 2006; Kristiansen 1998; Earle and Kristiansen 2010; Price and Feinman 2010; Carneiro, Grinin, and Korotayev 2017; Chacon and Mendoza 2017, etc.). This leads to the conclusion that another line of social evolution - nonhierarchical societies - exists in parallel with the creation of hierarchal societies (chiefdoms and states). Hence, social evolution is multilinear.

To what extent can these theories be applied to pastoral nomads? It is obvious, that the nomadic empires were polities with developed hierarchies. For instance, in the Xiongnu empire (209 BC - 48 AD) there existed many different variants of funerary rituals, which display a developed differentiation of ranks and social statuses (Kradin 2005). Local and imported prestige goods were concentrated among the elite ('terrace') kurgans. The elite controlled their production, import, and distribution. Sta- 
tus and hierarchy are reflected in the ideological system, as well as in the mortuary architecture (Brosseder 2009).

The analysis of Slab graves (or Slab burials) culture in Mongolia and Transbaikalia, shows a completely different situation. This culture dates back to approximately $1000-300$ BC. It was widespread before the time of the Xiongnu. The study of various Slab graves shows three or four social ranks with no rigid borders between them. Different groups within the society had identical (or nearly identical) access to resources (pastures and animals) and strong social inequality was not formed. The economic efforts of society were aimed at solving collective goals. They had religious cults and rituals common for all. Perhaps, this culture also had a universal cosmology, as well as a standardized lifestyle. Most likely, the Slab grave culture was the so-called middle-scale society, which can also be described as a heterarchy (Kradin 2019). The khirigsuur culture of Inner Asia displays a closely similar social setup (Honeychurch, Wright, and Amartuvshin 2009; Fitzhugh 2009; Houle 2009; Wright 2017).

It is likely that in the case of the pastoral nomads heterarchy and hierarchy should not be considered as two separate directions. Rather, they are two different levels of political centralization. At the level of weak authority, the nomads can be structured into a heterarchical tribe or chieftainship. As personal authority grows, they are transformed into a hierarchical chiefdom. A multitude of combinations and dichotomies of the heterarchical and hierarchical polities is possible among the nomads. The group of heterarchical tribes can be united into an acephalic polity or a weak chiefdom. In turn, simple chiefdoms can be structured into a complex chiefdom or a heterarchical confederacy of chiefdoms. The Khitan 'eight polities' confederation of the first millennium AD can be considered an example of the latter (Kradin, Ivliev 2014). All these structures were as unstable as steppe tumbleweed as both the number of segments and the character of the internal ties were constantly changeable. Often the heterarchy - hierarchy dichotomy depended on various factors, including the individual qualities of political leaders. For example, with the lucky charismatic leader in power, a complex chiefdom hierarchy could be built. After his death, it could transform into a heterarchical confederation of chiefdoms.

According to the 'Montesquieu law' a democratic republic is characteristic of small polities, whereas a kingdom is characteristic of mid-sized polities and empire - of the large ones (Korotayev 1995: 64-65). The steppe had a low population density. Pastoralists need a lot of grass to feed their cattle. That is why large numbers of nomads can live only on a large territory. The bigger the polity is, the more hierarchical its structure must be. Keeping the power hierarchy intact requires personal authority and charisma of the leader. For this very reason, the nomads did not have 
complex heterarchical polities with high population density, like ancient Greece or Rome.

Comparative data help to better understand how heterarchy and hierarchy correlate in prehistoric pastoral nomadic societies. Numerous ethnohistoric studies confirm the existence of these two forms of communication networks and social organization among the pastoral nomads. The African pastoralists had horizontal reciprocity networks, such as marriage compensations and sharing of animals for group communications and the support of survivors of crises and famine (Evans-Pritchard 1940; Gulliver 1955; Spencer 1973; Goldschmidt 1974). In the Middle East, as well as Central and Inner Asia hierarchical patron-client relationships are more common. Rich nomads provide resources for the needy and poor pastoralists (Barth 1961; Black-Michaud 1972; Irons 1975, 1994; Beck 1980; Bradburd 1989).

Of course, reciprocity exists not only in Africa (Irons 1975; Cooper 1993), and patron-client relations are known to the African pastoralists, such as the Maasai (Little 1985; Ensminger 1992). It is important to note that the poor are more at risk for losing a herd. Rich households are more stable and they are a source of inequality networks (Bradburd 1982; Fratkin and Roth 1990; Roth 1996). The mobility of nomads prevents the establishment of a developed hierarchy among the pastoralists. People can always migrate from a cruel chieftain to another territory. Access of every male nomad to weapons also contributes to the independence of the nomads. Mobile lifestyle is more in line with decentralization and heterarchy than hierarchy.

The presence of settled neighbors provides a stimulus for the consolidation and formation of an internal hierarchy. The struggle for access to non-pastoral resources forces nomads to unite. Anthropologists have long noted that egalitarian and decentralized societies are more likely in remote regions, whereas chiefdoms and confederations are more likely to form in areas where there are agricultural settlements and towns, markets and power. That is why pastoralist confederations with internal hierarchy emerge where there is a confrontation with the sedentary people (Irons 1979; Fletcher 1986; Beck 1986; Salzman 2002, 2004). Hence, heterarchy and hierarchy among the nomads are not two different vectors of transition processes, but more likely, two fields. The first one is characteristic of pastoral societies, which have no developed contacts with the agricultural societies. The second variant is found among pastoral nomads who constantly communicate with settled people. Therefore, the more complex the settled agricultural society is, the more complex the nomadic confederation should be. For communications with small oases, a tribal confederacy or a chiefdom is enough, but the interaction with an agricultural civilization requires a nomadic empire. 


\section{POSTMODERNISM}

In the era of postmodernism, courtesy of Gilles Deleuze and Felix Guattari, the term nomadology became a kind of manifesto, a philosophy of protest against the total power of the contemporary state (Deleuze and Guattari 2010). Gradually, these ideas became quite widespread in the humanities' discourse (see, e.g., Oushakine 2012). At the same time, studies appeared in Western archaeology and anthropology that refuted the well-entrenched theories of the historical process and sociocultural evolution from the perspective of postmodernism. Much criticism was directed at the chiefdom theory (Yoffee 2005; Pauketat 2007; Routledge 2014).

Postmodernism also penetrated into nomadic studies in anthropology and archaeology. Cambridge anthropologist David Sneath's book The Headless State became a bright example of postmodernist discourse. Back in the late 1990s, he was still far from this theme and without hesitation considered it possible to apply the term feudalism to nomads, having borrowed it from the leading Mongolian historians (Humphrey and Sneath 1999: 219). However, at the 2004 Cambridge symposium on the history of power institutions in Inner Asia, he announced his new approach and a little later published a monograph and a series of other studies on this problem (Sneath 2007, 2009, 2013, etc.).

The book is permeated with the spirit of anti-evolutionism. The author actively opposes the colonial theory of egalitarian nomads, which, in his view, was created to demonstrate the backwardness of the steppe societies. It is exactly due to this that the colonial anthropologists used the terms clan and tribe (the later scholars also coined the term chiefdom) to describe the political system of nomads. Reading this book, one gets a feeling of a global conspiracy of anthropologists from developed countries against poor tribes. Sneath agrees with the fact that the Mongolian nomadic society had stratification and tries to construct a concept of 'aristocratic society' of the nomads, for which he coined his own definition of 'headless state' (perhaps, a functionalist remake of the term acephalous society by Edward EvansPritchard [1940]).

The monograph received rave reviews in postmodernist literature. At the same time, it was rather critically reviewed by nomadologists. ${ }^{1}$ The key complaint is not even in the clumsy term (one can only ironicize matching the definition of a headless state to, e.g., Genghis Khan's Mongolian Empire), but in anti-historicism and systemic distortion of facts and other people's concepts, indiscriminately attributing to the earlier scholars errors that they did not commit.

I will give just a single example. Sneath attributes the creation of the definition tribe to Lewis Henry Morgan, the classic evolutionist. However, this term was known in the English language long before Morgan. It traces its origins to the Latin word tribus. The Russian variant 
plemia (племя) originated in the Old Slavonic language. Similar words can be found in Czech, Polish, Croatian, and other Slavic languages. Alexey Levshin, whose book Sneath cites and criticizes, published his volume on Central Asian nomads in 1832, that is several decades prior to the publication of Morgan's Ancient Society (1877), where the main principles of evolutionism were formulated. In other words, Levshin had used the notion tribe not simply before the advent of evolutionism, but also before social anthropology formed as a branch of social science.

\section{DISCUSSION}

Summing up certain results of the discussion on the ratio between internal and external factors, Nicola Di Cosmo expressed the opinion that there are three persistent misconceptions in contemporary nomadology (2015). The first concerns the rigid division between the nomadic world and the sedentary world. In his view, nomads were familiar with agriculture from times immemorial. It is difficult to dispute this idea because the nomads, to one degree or another, practiced embryonic forms of agriculture. This is confirmed by numerous archaeological and ethnographic data. The key issue is to what extent agriculture was spread in steppe societies? Were these scales comparable to the economies of settled agricultural states?

According to Di Cosmo, the second misconception concerns Barfield's hypothesis about the synchronicity of the processes of the rise and fall of nomadic empires and the neighboring agricultural civilizations. It is hard to disagree with this criticism. The formation of the Xianbei imperial confederation, as well as Turk and Uighur Khaganates in no way correlates with the heyday of the Chinese dynasties.

The third misconception concerns the widespread stereotypes about nomads, which can be found in the writings of the ancient chroniclers, from Herodotus to Sima Qian. They are, indeed, alike, but this does not mean that they copied one another. Undoubtedly, contemporary researchers must know how to separate the Sedentarist (nomadic variant of Orientalism) discourse of a resident of a sedentary society from reliable facts. However, this does not mean that everything written is meaningless.

In a somewhat exaggerated form, the description of pastoral nomads was presented in Christopher Beckwith's book Empires of the Silk Road. He suggests that the nomads received all necessary resources from trade or direct taxation, and so-called pure nomads never existed. The population of the steppe always engaged in agriculture and crafts and sustained itself independently. Narrative sources are too tendentious in picturing the nomads as warlike and aggressive barbarians. This is a persistent myth created in the sedentary environment. Indeed, the nomads were superb archers and horse riders. However, they were no crueler than their Southern neighbors (it is hard to disagree with the latter statement). At the same 
time, nomads were environmentally vulnerable (since zud or fodder shortages could easily destroy their supplies) and were easy prey for the neighbors (since they had no fortified towns and their population was much smaller). Beckwith comes to the conclusion that it was the sedentary-urban empires seeking expansion and conquest of their neighbors that were mostly to blame for the conflicts between the steppe and sedentary peoples (Beckwith 2009).

Many of Beckwith's arguments do not hold ground. He believes that infantry is stronger than cavalry and the guerilla tactics of nomadic forays were the weapon of the weak. In reality, in the period between 550 and $1350 \mathrm{AD}$ after the invention of stirrups and saddle, it was heavy cavalry that ruled the battlefield. Moreover, under the conditions of split fronts cavalry always had an advantage in mobility. The nomadic tactics were not guerilla warfare, but a hybrid war, which was best suited to the natural conditions of vast and open steppe and forest-steppe spaces that gave cavalry tactical amplitude.

Repeating this thesis that nomads practiced agriculture and built towns, Beckwith forgets to compare the scale and give concrete facts. The nomads did, indeed, practice some embryonic agriculture, but the question remains how well that incipient agriculture satisfied their need in carbohydrates. As for the urbanization one has to bear in mind the fact that the Xiongnu, for example, had only one real town known today (the Ivolga fortress in Buryatia). Fifteen other settlement sites are not towns (Kradin et al. 2017). Considering that the population of the Xiongnu empire numbered less than a million people (Kradin 2002: 79), the number of towns is negligible. For instance, according to the archaeological data, even on the northern borders of the Han Empire contiguous with the Xiongnu, there was a multi-level hierarchy of settlements and towns of various ranks and sizes (Bo and Shelach 2014).

The problem is not in the fact that the nomads did or did not practice agriculture. Nomads cannot exist without agricultural societies. They can form even complex societies (Pazyryk, Tagar, and Slab grave cultures). However, there is not a single nomadic empire that would emerge earlier than the neighboring sedentary agricultural empires and this, in my view, is the main argument in favor of the fact that there is a real connection between centralization in the steppe and the sedentary world.

Another question is: if the societies of pastoralists and nomads can independently create statehood, why then, for example, the Nuer or Chukchi did not form a steppe empire? According to Evans-Pritchard, the $\mathrm{Nu}-$ ers population exceeded 200,000 (1940: 117) and from time to time they attacked the Dinka. The Chukchi periodically terrorized their neighbors with raids against them (Nefedkin 2003). Why were they non-empires? 


\section{COMMENTS TO THE ARTICLES OF THE SPECIAL SECTION}

The articles in this special section discuss a variety of subjects in anthropology and history of pastoral nomads of Inner Asia. Marina Sodnompilova and Bair Nanzatov are both anthropologists. Their field of expertise is Mongols and Buryats. In their recent studies, they continue the important work of Natalia Zhukovskaya (1984) and elaborate the basic foundations of pastoral nomadic culture. In their contribution, they turn to the analysis of ideas about space and time in the nomadic pastoral societies. Their research shows that the perception of the world by the steppe peoples is ecologically mediated. The perception of space and the ability to orient oneself in the steppe is a very important part of the nomadic culture. I often saw how the Mongols masterfully read the topography on the horizon. In places where an anthropologist from the concrete jungle sees no bearings, the nomads perceive the terrain as simply a fragment of a mental map, which is always with them. If for a settled person a journey into the uncharted territory means a psychological stress, for a nomad it is just life and the blessing of mobility. Sodnompilova and Nanzatov unfold an intricate and multi-level panorama of the pastoralists' ideas about various parts of space around them, their markers and borders.

The article by archaeologists William Honeychurch, Jargalan Burentogtokh, and William Gardner presents a broad panorama of the Late Bronze Age and Early Iron Age in Central Mongolia. The authors show how communication, technological, economic, and ideological networks developed gradually, step by step, passing through such important stages as the domestication of the horse, the spread of the chariot, and horse riding. It was particularly important for Central Mongolia that it was the crossroads of cultural traditions coming from the West and the Southwest. The complexity pointed out in this paper is not the fixed structure, but, using the intellectually fashionable words of Pierre Bourdieu, a field of communication created by thousands of daily micro-decisions.

Archaeologists Alexey Tishkin and Petr Dashkovsky discuss the issue of whether Pazyryk society can be considered a state. They have long carried out excavations of archaeological remains of this culture. In their article, they gathered abundant data confirming the complexity of the Pazyryk polity. However, they do not explain how they define a state. There are two different meanings of this notion. In its first definition, the state is a country or a nation-state. This meaning is most often used in everyday speech. The second meaning of the state is an administrative apparatus. This understanding of the state is more often used in specific academic texts (Bourdieu 2014: 31-32). If one considers the Pazyryk society as a country or an independent polity, it is definitely a state. However, it is quite doubtful to find a state in the Pazyryk society in the second meaning of the word. As Karl Wittfogel succinctly and rightfully stated, 
the state is 'government by professional' (1957: 239). There is no information whatsoever about professional bureaucrats in the Pazyryk society.

Unlike Tishkin and Dashkovsky, Sergey Vasyutin explains in detail that there was no bureaucratic apparatus in nomadic empires. The everyday practices of the steppe elite hardly differed from the responsibilities of tribal leaders and chieftains. Ancient and medieval nomadic empires had no written legislation or taxes. Vasyutin tends to conclude that the nomadic empires were not states. Following Grinin and Bondarenko, he prefers the term of analogues of the states and homoarchies. Only when nomads started to have close relationships with the sedentary peoples did they create a state (e.g., Uyghurs, Khitans).

To a certain extent, this article sums up Vasyutin's previous publications $(2003,2015)$. Apart from the 'implacable' issue about the state he pays attention to two other topics, namely, the characteristic traits of nomadic empires and their types. In the first question, he follows the old tradition (Kradin 1996, 2000), but his scrupulous supplements and refinements add more detail to his descriptions. In a certain sense, it is, indeed, a 'thick description.' To this or that extent, these conclusions match the viewpoints of other authors (Rogers 2012: 208-209; Biran 2015: 2-3).

Typology is a pet subject for the Russian archaeologists. Western scholars have long been interested in other topics, such as the growth and collapse of empires, postmodern interpretation of texts, and historical memory. From time to time the anthropologists leaning toward neoevolutionism express the idea to consider the typologies of social systems more seriously (e.g., Wason 1995). In Russia the situation is different. Many scholars are sure that classification is the best theory. Vasyutin has long been trying to create a universal typology of pastoral empires (2015). Gradually, he has come to a dual typology, which resembles Khazanov's typology (1984). In this article, he thoroughly describes two models of imperial nomads. I singled out three models (Kradin 2000). This reminds me of an endless controversy: what is better, two or three? Or four after all? I think it is more a question of taste or aesthetics than scientific proof. Perhaps, my European ancestry made me subconsciously lean towards the Christian Triad, but not towards tribal binary oppositions.

In fact, other issues, such as for example, the continuity between ancient and medieval empires, are far more important. This issue was first investigated by Vadim Trepavlov, who attempted to explain the similarity between the Mongolian Empire and the earlier polities of the Xiongnu and Turks (Trepavlov 1993). Since diffusionist ideas were unpopular at that time, Trepavlov's concept got no further development. It took some time for Daniel Rogers to draw attention to this problem again with new arguments (2007). 
The next two articles discuss the Turkic Khaganate. Vladimir Tishin is an encyclopedic Turkologist. Several years ago he wrote his $\mathrm{PhD}$ thesis about the social organization of the Turkic Khaganate (Tishin 2015). The dissertation manuscript was huge. Tishin probably took into account all studies published in all languages. In his small article, he presented all narrative sources about family and concluded that the Turks had a nuclear family, whereas speculations about a large family were simply a myth created by the old-school Marxist scholars.

While Tishin's study of the Turk society is based on the medieval chronicles, Nikolai Seregin uses archeological data in his research on this issue (2013). In his article, he summarized his previous studies of the social differentiation of the Turk khaganate based on evidences from burial sites. He marked the age inequality and gender division of labor in the funeral rite noting the great importance of war for the nomads. Of particular interest is his observation about different meanings of artifacts found in the grave. He distinguishes objects of power (scarce arms, cauldrons) and objects of wealth (ornament belts and buckles, important prestige goods). The analysis of social structure led him to the conclusion that there were defined nine ranks among men, four ranks among women, and three ranks among children. Seregin is cautious and does not try to link the ranks with known social status levels in the Turk society.

Such a study is best done in collaboration with someone proficient in ancient languages. Tishin and Seregin jointly wrote an excellent book that combines their knowledge of narrative and archaeological sources (Seregin and Tishin 2017). This is a promising result since the twentieth century is the age of specialised scholars. Due to the rapidly increasing information volume, it is difficult to simultaneously master the craft of several disciplines. As a rule, archaeologists do not speak Oriental languages while the orientalists and ethnologists are poorly trained in archaeology. As a result, a researcher sees the object of study only through the methodological prism and theoretical tradition of his own discipline missing things that relate to other disciplines.

Moreover, even within one discipline, there are often regional and chronological specializations. Not surprisingly, the researcher of Eastern European steppes creates a model of pastoral society and then extrapolates it to Inner Asia. In the same manner, the researcher of Inner Asia involuntarily extrapolates the imperial models to Central Asia or the Circum-Pontic region, whereas a fundamentally different ecological and geopolitical situation existed there. For many anthropologists, who have seen the everyday practices and lifestyle of the nomads, it seems strange to find a state in the steppe. An archaeologist who excavated the colossal funeral complexes or steppe towns, by contrast, will most probably think that the nomads did, indeed, create states and empires. 
Three levels of theories are distinguished in anthropology: great theories, middle-range theories, and thick description (Ellen 2010). Many important questions concerning the description of pastoral nomadic societies do not produce diverse interpretations. However, there is still no consensus on several fundamental issues. Scholars argue about the nature of large nomadic polities, whether they were supercomplex chiefdoms or states. There is no unanimity on the role of external and internal factors and relationships with the agricultural civilizations. In terms of thick description, we see considerable progress in the description of the basic features of nomadic culture ( $c f$. Zhukovskaya 1984; Sodnompilova 2005). Middle range theories (Merton 1968) or empirical theories (Smith 2011) are theories that can be used to explain the phenomena of various levels but do not suit for the comprehensive interpretation of every social phenomenon without exception. In other words, it is a complex of instruments capable of interpreting a limited set of facts or phenomena (Hedström, Udéhn 2009: 31). Middle range theories can be partially included in the higher-level theories, but at the same time, they can have completely independent significance for the understanding of various aspects of the universe. In nomadology, the examples of such theories may be the livelihoods of local communities of pastoral nomads in longue duree (Honeychurch 2015) or nomadic urbanization (Kradin 2018b). But greater prospects are yet to come.

\section{NOTES}

This study has been supported by the mega-grant of the Government of Russian Federation (№ 14.W03.31.0016) 'Dynamics of peoples and empires in Inner Asia'.

${ }^{1}$ Among the reviewers there were P. Golden (Journal of Asian Studies, Vol. 68, 2009, No 1: 293-296), T. Barfield (Comparative Studies in Society and History, 2009, No 4: 942-943), A. Khazanov (Social Evolution and History, 2010, No 2: 206-208), etc. Sneath answered P. Golden's review with a polemic rebound (Journal of Asian Studies, Vol. 69, 2010, No 2: 658-660), to which Golden gave the argumentative answer (Ibid.: 660-663). The Ab Imperio journal (2009, № 4: 80-175) devoted a special section to the discussion of David Sneath's concept.

\section{REFERENCES}

Barfield, T. 1992. The Perilous Frontier: Nomadic Empires and China, 221 BC to $A D$ 1757. Cambridge: Blackwell (First published in 1989).

Barfield, T. 1993. The Nomadic Alternative. Englewood Cliffs: Prentice Hall.

Barfield, T. 1995. Explaining Crisis and Collapse: Comparative Succession Systems in Nomadic Empires. In Schorkowitz, D. (ed.), Etnohistorische Wege und Lehrjahre eines Philosophen. Festschrift fur Lawerence Krader zun 75. Geburtstag (pp. 187-209). Frankfurt am Main etc.: Peter Lang. 
Barfield, T. 2001. The Shadow Empires: Imperial State Formation along the Chinese-Nomad Frontier. In Sinopoli, C., D'Altroy, T., Morrision, K., and Alcock, S. (eds.), Empires (pp. 10-41). Cambridge: Cambridge University Press.

Barfield, T. 2003. Conclusion. In Kradin, N. N., Bondarenko, D. M., and Barfield, T. (eds.), Nomadic Pathways in Social Evolution (pp. 172-179). Moscow: Center for Civilizational and Regional Studies of the Russian Academy of Sciences.

Barth, F. 1961. Nomads of South Persia. Boston, MA: Little, Brown.

Bazarov, B. V., Kradin, N. N., and Skrynnikova, T. D. (eds.) 2004-2008. Mongolian Empire and Nomadic World. Vols 1-3. Ulan-Ude: Publishing House of the Buryatian Scientific Center SB RAS. Original in Russian (Базаров Б. В., Крадин Н. Н., Скрынникова Т. Д. (ред.), Монгольская империя и кочевой мир. Кн. 1-3. Улан-Удэ: Изд-во БНЦ СО РАН).

Beck, L. 1980. Herd Owners and Hired Shepherds: The Qashqa'I of Iran. Ethnology 19(3): 327-351.

Beck, L. 1986. The Qashqa'i of Iran. New Haven: Yale University Press.

Beckwith, C. 2009. Empires of the Silk Road: A History of Central Eurasia from the Bronze Age to the Present. Princeton: Princeton University Press.

Berezkin, Yu. E. 1995. Alternative Models of the Middle Range Society. 'Individualistic' Asia vs. 'Collectivistic' America? In Kradin, N. N., and Lynsha, V. A (eds.), Alternative Pathways to Early State (pp. 75-92). Vladivostok: Dalnauka.

Berezkin, Yu. E. 2000. Once Again on Horizontal and Vertical Links in Structure of the Middle Range Societies. In Kradin, N. N., Korotayev, A. V., Bondarenko, D. M., de Munck, V., and Wason, P. K. (eds.), Alternatives of Social Evolution (pp. 220-224). Vladivostok: Far-Eastern Branch of the Russian Academy of Sciences.

Biran, M. (ed.) 2015. Nomads as Agent of Cultural Change: The Mongols and Their Eurasian Predecessors. Honolulu: University of Hawai'i Press.

Black-Michaud, J. 1972. Tyranny as a Strategy for Survival in an 'Egalitarian' Society: Luri Facts versus an Anthropological Mystique. Man 7: 614-634.

Blanton, R., Feinman, G., Kowalewski, S., and Peregrine, P. 1996. A Dual-processual Theory for the Evolution of Mesoamerican Civilization. Current Anthropology 37(1): 1-14, 73-86.

Bo Ch., and Shelach, G. 2014. Fortified Settlements and the Settlement System in the Northern Zone of the Han Empire. Antiquity 88 (339): 222-240.

Bondarenko, D. M. 2006. Homoarchy: A Principle of Culture's Organization. The $13^{\text {th }}-19^{\text {th }}$ Centuries Benin Kingdom as a Non-State Supercomplex Society. Moscow: KomKniga.

Bondarenko, D. M., and Korotayev, A. V. (eds.) 2000. Civilizational Models of Politogenesis. Moscow: Center for Civilizational and Regional Studies of the Russian Academy of Sciences.

Bonte, P. 1981. Marxist Theory and Anthropological Analysis: The Study of Nomadic Pastoralist Societies. In Khan, J., and Llobera, J. (eds.), The Anthropology of Pre-capitalist Societies (pp. 22-55). London and Basingstoke: The Macmillan Press. 
Bonte, P. 1990. French Marxist Perspectives on Nomadic Societies. In Salzman, P. C., and Galaty, J. G. (eds.), Nomads in a Changing World (pp. 49-101). Naples: Instituto Universitario Orientale. Dipartimento di Studi Asiatici.

Bourdieu, P. 2014. On the State: Lectures at the Collège de France, 1982-1992. Cambridge: Polity Press.

Bradburd, D. 1982. Volatility of Animal Wealth among Southwest Asian Pastoralists. Human Ecology 10 (1): 85-106.

Bradburd, D. 1984. Marxism and the Study of Pastoralists. Nomadic Peoples 16: 3-14.

Bradburd, D. A. 1989. Producing their Fates: Why Poor Basseri Settled but Poor Komachi and Yomut did not. American Ethnologist 16: 502-518.

Brosseder, U. 2009. Xiongnu Terrace Tombs and their Interpretation as Elite Burials. In Bemmann, J., Parzinger, H., Pohl, E., and Tseveendorzh, D. (eds.), Current Archaeological Research in Mongolia (pp. 247-280). Bonn: FridrichWilhelms-Universität Bonn.

Burovsky, A. M. 1995. The Pastoral Steppe Civilization: Criteria, Description, AnaLysis, and Correlations. Tsivilizatsii 3 (Moscow): 151-164. Original in Russian (Буровский А. М. Степная скотоводческая цивилизация: критерии описания, анализа и сопоставления. Цивилизации. Вып. 3: 151-164).

Carneiro, R., Grinin, L. E., and Korotayev, A. V. (eds.) 2017. Chiefdoms: Yesterday and Today. New York: Elliot Werner Publications, Inc.

Chacon, R., and Mendoza, R. (eds.) 2017. Feast, Famine or Fighting? Multiple Pathways to Social Complexity. New York: Springer.

Chernykh, E. 2017. Nomadic Cultures in the Mega-Structure of the Eurasian World. Boston: Academic Studies Press.

Cooper, L. 1993. Patterns of Mutual Assistance in the Mongolian Pastoral Economy. Nomadic Peoples 33: 153-162.

Crumley, C. 1995. Heterarchy and the Analysis of Complex Societies. Ehrenreich, R. M., Crumley, C. L. and Levy, J. E. (eds.), Heterarchy and the Analysis of Complex Societies (pp. 1-5). Washington, D. C.: American Anthropological Association.

Crumley, C. 2001. Communication, Holism, and the Evolution of Sociopolitical Complexity. In Haas, J. (ed.), From Leaders to Rulers (pp. 19-36). New York: Kluwer Academic.

Deleuze, G., and Guattari, F. 2010. Nomadology. The War Machine. Seattle: Wormwood Distribution.

Di Cosmo, N. 1999. State Formation and Periodization in Inner Asian History. Journal of World History 10: 1-40.

Di Cosmo, N. 2002. Ancient China and its Enemies: The Rise of Nomadic Power in East Asian History. Cambridge: Cambridge University Press.

Di Cosmo, N. 2011. Ethnogenesis, Coevolution and Political Morphology of the Earliest Steppe Empire: the Xiongnu Question Revisited. In Brosseder, U., and Miller, B. (eds.), Xiongnu Archaeology: Multidisciplinary Perspectives of the First Steppe Empire in Inner Asia (pp. 35-48). Bonn: Rheinische Friedrich-Wilhelms-Universitat Bonn. 
Di Cosmo, N. 2015. China-Steppe Relations in Historical Perspective. In Bemmann, J., and Schmauder, M. (eds.), Complexity of Interaction along the Eurasian Steppe Zone in the First Millennium CE (pp. 49-72). Bonn: University of Bonn.

Digard, J.-P. 1989. Relations between Nomads and Settled Tribes in the Middle East. In Masson, V. M. (ed.), The Interaction between Nomadic Cultures and Ancient Civilizations (pp. 33-54). Alma-Ata: Nauka. Original in Russian (Дигар Ж.-П. Отношения между кочевниками и оседлыми племенами на Среднем Востоке. Массон, В. М. (ред.), Взаимодействие кочевых культур и древних цивилизаиий (с. 33-54). Алма-Ата: Наука).

Drompp, M. 2005. Imperial State Formation in Inner Asia: The Early Turkic Empires $\left(6^{\text {th }}\right.$ to $9^{\text {th }}$ Centuries). Acta Orientalia Academiae Scientiarum Hungaricae 58 (1): 101-111.

Dyson-Hudson, R., and Dyson-Hudson, N. 1980. Nomadic Patoralism. Annual review of Anthropology 9: 15-61.

Earle, T., and Kristiansen, K. (eds.) 2010. Organizing Bronze Age Society. Cambridge: Cambridge University Press.

Ellen, R. 2010. Theories in Anthropology and 'Anthropological Theory'. Journal of the Royal Anthropological Institute 16: 387-404.

Enkhtuvshin, B. 2003. Nomadic Society and Some Aspects of Civilizations Studies. In Enkhtuvshin, B., and Tsolmon, J. (eds.), Chinggis Khaan and Contemporary Era (pp. 65-90). Ulaanbaatar.

Ensminger, J. 1992. Making a Market: The Institutional Transformation of an African Society. Cambridge: Cambridge University Press.

Evans-Pritchard, E. 1940. The Nuer: A Description of the Modes of Livelihood and Political Institutions of a Nilotic People. London: Oxford University Press.

Fletcher, J. 1986. The Mongols: Ecological and Social Perspectives. Harvard Journal of Asiatic Studies 46 (1): 11-50.

Fitzhugh, W. 2009. Pre-Scythian Ceremonialism, Deer Stone Art, and Cultural Intensification in Northern Mongolia. In Hanks, B., and Linduff, K. (eds.), Social Complexity in Prehistoric Eurasia: Monuments, Metals, and Mobility (pp. 378-411). Cambridge: Cambridge University Press.

Fratkin, E., and Roth, E. A. 1990. Drought and Economic Differentiation among Ariaal Pastoralists of Kenya. Human Ecology 18: 385-402.

Gellner, E. 1988. State and Society in Soviet Thought. Oxford: Oxford University Press.

Golden, P. 1991. The Qipčaqs of Medieval Eurasia: An Example of Stateless Adaptation in the Steppes. In Seaman, G., and Marks, D. (eds.), Rulers from the Steppe: State Formation on the Eurasian Periphery (pp. 132-157). LosAngeles: University of South California.

Golden, P. B. 1992. An Introduction to the History of the Turkic Peoples: Ethnogenesis and State Formation in Medieval and Early Modern Eurasia and the Middle East. Wiesbaden: Otto Harrassowitz. 
Golden, P. B. 2001. Ethnicity and State Formation in Pre-Činggisid Turkic Eurasia. Bloomington, IN: Indiana University, Department of Central Eurasian Studies.

Golden, P. B. 2011. Studies on the Peoples and Cultures of the Eurasian Steppes. Bucurest and Braila: Editura Academiei Române - Muzeul Brăilei Editura Istros.

Golden, P. 2015. The Stateless Nomads of Early Medieval Central Eurasia. Materialy po arkheologii, istorii i etnografii Tavrii 20: 333-368.

Goldschmidt, W. 1974. The Economics of Brideprice among the Sebei in East Africa. Ethnology 13: 311-331.

Grinin, L. E., Carneiro, R. L., Bondarenko, D. M., Kradin, N. N., and Korotayev, A. V. (eds.) 2004. The Early State, Its Alternatives and Analogues. Volgograd: Uchitel.

Griaznov, M. P. 1939. Early Nomads of Western Siberia and Kazakhstan. In Artamonov, M. I. (ed.), History of the USSR from Ancient Times to the Formation of the first Russian State (layout edition of the USSR Academy of Sciences) (pp. 399-413). Moscow - Leningrad: Academy of Sciences of the USSR Press. Original in Russian (Грязнов М. П. Ранние кочевники Западной Сибири и Казахстана. В: Артамонов, М. И. (ред.), История СССР с древнейших времен до образования первого русского государства (макет издания АН СССР) (с. 399-413). М. - Л.:. Изд-во АН СССР).

Gulliver, P. H. 1955. The Family Herds: A Study of Two Pastoral Tribes in East Africa the Jie and Turkana. London: Routledge \& Kegan Paul.

Haas, J. (ed.) 2001. From Leaders to Rulers. New York: Kluwer Academic/Plenum Publishers.

Halil, I. 1983. The Study of Economy and Social Relations among the Nomads of Asia (including South Siberia) in Soviet Anthropology of the 1950-1980s). Unpublished Ph.D. thesis. Moscow: Moscow University Press. Original in Russian (Халиль, И. Исследование хозяйства и общественных отношений кочевников Азии (включая Южную Сибирь) в советской литературе 50-80 гz.: Автореф. дис. ...канд. ист. наук. М.).

Hedström, P., and Udéhn, L. 2009. Analytical Sociology and Theories of the Middle Range. In Hedström, P., and Bearman, P. (eds.), The Oxford Handbook of Analytical Sociology (pp. 25-49). New York: Oxford University Press.

Honeychurch, W. 2013. The Nomad as State Builder: Historical Theory and Material Evidence from Mongolia. Journal of World Prehistory 26 (4): 283-321.

Honeychurch, W. 2014. Alternative Complexities: The Archaeology of Pastoral Nomadic States. Journal of Archaeological Research 22: 277-326.

Honeychurch, W. 2015. Inner Asia and the Spatial Politics of Empire: Archaeology, Mobility, and Culture Contact. New York: Springer.

Honeychurch, W. 2017. The Development of Cultural and Social Complexity in Mongolia. In Habu, J., Lape, P., and Olsen, J. (eds.), Handbook of East and Southeast Asian Archaeology (pp. 513-532). New York: Springer. 
Honeychurch, W., Wright, J., and Amartuvshin, C. 2009. Re-writing Monumental Landscapes as Inner Asian Political Process. In Hanks, B., and Linduff, K. (eds.), Social Complexity in Prehistoric Eurasia: Monuments, Metals, and Mobility (pp. 330-357). Cambridge: Cambridge University Press.

Houle, J.-L. 2009. Social Integrative Facilities and the Emergence of Societal Complexity on the Mongolian Steppe. In Hanks, B., and Linduff, K. (eds.), Social Complexity in Prehistoric Eurasia: Monuments, Metals, and Mobility (pp. 358-377). Cambridge: Cambridge University Press.

Humphrey, C., and Sneath, D. 1999. End of Nomadism? Durham: Duke University Press.

Irons, W. 1975. The Yomut Turkmen: A Study of Social Organization among Central Asian Turkic-Speaking Population. Ann Arbor: University of Michigan.

Irons, W. 1979. Political Stratification among Pastoral Nomads. In Pastoral Production and Society (pp. 361-374) Cambridge: Cambridge Univ. Press.

Irons, W. 1994. Why are the Yomut not More Stratified? In Chang, C., and Koster, H. A. (eds.), Pastoralists at the Periphery: Herders in a Capitalist World (pp. 175-196). Tucson: University of Arizona Press.

Jagchid, S. 1991. The Historical Interaction between the Nomadic Peoples in Mongolia and the Sedentary Chinese. In Seaman, G., and Marks, D. (eds.), Rulers from the Steppe: State Formation on the Eurasian Periphery (pp. 6391). Los-Angeles: University of South California.

Jagchid, S., and Symons, V. J. 1989. Peace, War, and Trade along the Great Wall: Nomadic-Chinese Interaction through Two Millennia. Bloomington, IN: Indiana University Press.

Kalinovskaya, K. P. 1996. On the Nomads in the Context of V. V. Matveev's book 'The Mediaeval Northern Africa.' Vostok/Oriens 4: 153-158. Original in Russian (Калиновская К. П. О кочевничестве в связи с книгой В. В. Матвеева 'Средневековая Северная Африка'. Восток 4: 153-158).

Khazanov, A. M. 1984. Nomads and the Outside World. Cambridge: Cambridge Univ. Press.

Kim, H. J. 2017. The Xiongnu. Oxford Research Encyclopedia of Asian History (pp. 1-28). Oxford: Oxford University Press.

Klyashtorny, S. G. 2012. The Main Stages of Politogenesis in the Ancient and Medieval Nomads of Central Asia. Nauchnyi Tatarstan 2: 74-84. Original in Russian (Кляшторный С. Г. Основные этапы политогенеза у древних и средневековых кочевников Центральной Азии. Научный Татарстан 2: 74-84).

Klyashtorny, S. G., and Savinov, D. G. 1994. The Steppe Empires of Eurasia. Saint Petersburg: Farn. Original in Russian (Кляшторный С. Г., Савинов Д. Г. Степные империи Евразии. СПб.: Фарн).

Klyashtorny, S. G., and Sultanov, T. I. 2000. The States and Nations of Eurasian Steppes. Antiquity and Middle Age. Saint Petersburg: Peterburgskoe vostokovedenie. Original in Russian (Кляшторный, С. Г., Султанов, Т. И. Государства и народь евразийских степей. Древность и средневековье. СПб.: Петербургское Востоковедение). 
Kogan, L. S. 1980. The Problems of Socio-Economic Organization of Nomadic Societies in Historical and Economical Thought. Unpublished Ph.D. thesis. Alma-Ata: Institute of economy, Academy of Science KazSSR. Original in Russian (Коган Л. С. Проблемы сочиально-экономического строя кочевых обществ в историко-экономической литературе (на примере дореволючионного Казахстана): Автореф. дисс. ...канд. экон. наук. М.).

Korotayev, A. V. 1995. Mountains and Democracy: An Introduction. In Kradin, N. N., and Lynsha, V. A. (eds.), Alternative Pathways to Early State (pp. 60-74). Vladivostok: Dalnauka.

Koryakova, L. N. 1996. Social Trends in Temperate Eurasia during the Second and First Millennia BC. Journal of European Archaeology 4 (1): 243-280.

Koryakova, L. N. 2002. Social Landscape of Central Eurasia in the Bronze and Iron Ages: Tendencies, Factors and Limits of Transformation. In Jones-Bley, K., and Zdanovich, D. (eds.), Complex Societies of Central Eurasia from the $3^{\text {rd }}$ to the $1^{\text {st }}$ Millennium BC: Regional Specifics in Light of Global Models (pp. 97118). Journal of Indo-European Studies Monograph Series 45. Washington, D.C.: Institute for Study of Man.

Koryakova, L. N., and Epimakhov, A. E. 2007. The Ural and Western Siberia in the Bronze and Iron Ages. Cambridge: Cambridge University Press.

Kradin, N. N. 1992. Nomadic Societies. Vladivostok: Dalnauka. In Russian (Kpaдин Н. Н. Кочевые общества. Владивосток: Дальнаука).

Kradin, N. N. 1996. Specific Features of Nomadic Empires. In Danilov, S. V. (ed.), International Archaeological Congress 'Anniversary of Hsiung-nu Archaeology. Nomadism - Past, Present in Global Context and Historical Perspective. The Phenomenon of the Hsiung-nu' (pp. 176-178). Ulan-Ude: Publishing House of the Buryatian Scientific Center SB RAS.

Kradin, N. N. 2000. Nomadic Empires in Evolutionary Perspective. In Kradin, N. N., Korotayev, A. V., et al. (eds.), Alternatives of Social Evolution (pp. 274-288). Vladivostok: Far-Eastern Branch of the Russian Academy of Sciences.

Kradin, N. N. 2002. Xiongnu Empire. $2^{\text {nd }}$ ed. Moscow: Logos. Original in Russian (Крадин Н. Н. Империя Хунну. 2-е изд. М.: Логос).

Kradin, N. N. 2003. Ernest Gellner and Debates on Nomadic Feudalism. Social Evolution \& History 2 (2): 162-176.

Kradin, N. N. 2005. Social and Economic Structure of the Xiongnu of the TransBaikal Region. Archaeology, Ethnology \& Anthropology of Eurasia 1: 79-86.

Kradin, N. N. 2006. Cultural Complexity of Pastoral Nomads. World Cultures 15 (2): 171-189.

Kradin, N. N. 2007. Nomads of Eurasia. Almaty: Daik-Press. Original in Russian (Крадин Н. Н. Кочевники Евразии. Алматы: Дайк-Пресс).

Kradin, N. N. 2014. Nomads of Inner Asia in Transition. Moscow: URSS.

Kradin N. N. 2018a. Nomads and the Theory of Civilizations. In Arnason, J., and Hann, C. (eds.), Anthropology and Civilizational Analysis. Eurasian Explorations (pp. 303-322). Albany: State University of New York Press.

Kradin, N. N. (ed.) 2018b. Towns of Mediaeval Empires of the Far East. Moscow: Izdatelstvo Vostochnaya literatura. Original in Russian (Крадин, Н. Н. (ред.). 
Города средневековых империй Дальнего Востока. М.: Издательство Восточная литература).

Kradin, N. N. 2019. Social Complexity in Slab Graves Culture. In Bazarov, B. V., Kradin, N. N. (eds.), Nomadic Empires of Eurasia in Archaeological and Interdisciplinary Studies: IV International Congress of Medieval Archeology of the Eurasian Steppes (pp. 46-48). Ulan-Ude: Publishing House of the Buryatian Scientific Center SB RAS.

Kradin, N. N., Bondarenko, D. M., and Barfield, T. (eds.) 2003. Nomadic Pathways in Social Evolution. Moscow: Center for Civilizational and Regional Studies of the Russian Academy of Sciences.

Kradin, N. N., and Ivliev, A. 2014. History of Khitans Empire Liao (907-1125). Moscow: Nauka - Vostochnaya literatura. Original in Russian (Крадин, Н. Н., Ивлиев А. Л. История киданьской империи Ляо (907-1125). М.: Восточная литература).

Kradin, N. N., Ivliev, A. L., Kharinsky, A. V., Ochir, A., Vasyutin, S. A., Kovychev, E. V., and Erdenebold, L. 2017. Excavations of Terelzijn-Durvulzin Fortress and Some Results of the Study of Xiongnu Urbanization. In Bazarov, B. V., and Kradin, N. N. (eds.), Urgent Issues of Archaeology and Ethnology of Central Asia. Proceedings of the $2^{\text {nd }}$ International Scientific Conference (pp. 163-175). Ulan-Ude: Publishing House of the Buryatian Scientific Center SB RAS. Original in Russian (Крадин, Н. Н., Ивлиев, А. Л., Харинский, А. В., Очир, А., Васютин, С. А., Ковычев, Е. В., Эрдэнэболд, Л. Раскопки городища Тэрэлжийн-Дурвулжин и некоторые итоги изучения хуннской урбанизации. В: Базаров Б. В., Крадин, Н. Н. (ред.), Актуальные вопросы археологии и этнологии Центральной Азии. Мат. II межд. научн. конф. (с. 163-175). Улан-Удэ, Изд-во БНЦ СО РАН).

Kradin, N. N., Korotayev, A. V., Bondarenko, D. M., de Munck, V., and Wason, P. K. (eds.) 2000. Alternatives of Social Evolution. Vladivostok: Far-Eastern Branch of the Russian Academy of Sciences.

Kradin, N. N., and Skrynnikova, T. D. 2006. The Genghis-Khan Empire. Moscow: Vostochnaya literatura RAN. Original in Russian (Крадин Н. Н., Скрынникова Т. Д. Империя Чингис-хана. М.: Восточная литература РАН).

Kramarovsky, M. 2005. Golden Horde as a Civilization. In The Golden Horde. History and Culture (pp. 163-175). Saint Petersburg: Slaviya. Original in Russian (Крамаровский М. Г. Золотая Орда как цивилизация. Золотая Орда. История и культура (с. 163-175). СПб.: Славия).

Kristiansen, K. 1998. Europe Before History. Cambridge: Cambridge University Press.

Kulpin, E. S. 2008. A Dispute about Civilizations. Zolotoordynskaia civilizatsiia 1: 7-13. Original in Russian (Кульпин Э. С. Спор о цивилизациях. Золотоордынская иивилизация 1: 7-13).

Kürsat-Ahlers, E. 1994. Zur frühen Staatenbildung von Steppenvölkern: über die Sozio- und Psychogenese der Eurasischen Nomadenreiche am Beispiel der Hsiung-Nu und Göktürken Skythen. Berlin: Duncker en Humblot. 
Kychanov, E. I. 1997. The Nomadic State from the Xiongnu to Manchu. Moscow: Vostochnaya literatura. Original in Russian (Кычанов Е. И. Кочевые государства от гуннов до маньчжуров. М.: Восточная литература).

Kychanov, E. I. 2010. The History of Ancient and Medieval States Bordering on China (from the Huns to the Manchu). Saint-Petersburg: Peterburgskoe lingvisticheskoye obshchestvo. Original in Russian (Кычанов Е. И. История приграничных с Китаем древних и средневековых государств (от гуннов до маньчжуров). 2-е изд. СПб.: Петербургское лингвистическое общество).

Lattimore, O. 1940. Inner Asian Frontiers of China. New York - London: American Geographical Society.

Legrand, J. 2011. Mongols et Nomades: Société, Histoire, Culture. Textes, communications, articles 1973-2011. Ulaanbaatar.

Little, P. D. 1985. Absentee Herdowners and Part-Time Pastoralists: The Political Economy of Resource Use in Northern Kenya. Human Ecology 13: 131-151.

Maekawa, K. 2006. New Perspectives on the Study of the Mongol Empire. Transactions of the International Conference of Eastern Studies 51: 128-133. Tokyo: The Institute of Eastern Culture.

Markov, G. E. 1989. The Theoretical Problems of Nomadism in Soviet Ethnology. In Markov, G. E. (ed.), Historiography of the Ethnographic Studies of the Peoples of the USSR and Foreign Countries (pp. 54-75). Moscow: Moscow State University Press. Original in Russian (Марков Г. Е. Теоретические проблемы номадизма в советской этнографической литературе. В: Марков, Г. Е. (ред.), Историография этнографического изучения народов СССР и зарубежных стран (с. 54-75). М.: Изд-во МГУ).

Markov, G. E. 2001. The Social Structure of the Nomads of Asia and Africa. In DeWesse, D. (ed.), Studies on Central Asian History in Honor of Yuri Bregel (pp. 319-340). Bloomington: Indiana University, Research Institute for Inner Asian Studies.

Markov, G. E. 1998. The History of the Study of Nomadism in Russian Anthropology: Theoretical Questions. Vostok/Oriens 6: 110-123. Original in Russian (Марков Г. Е. Из истории изучения номадизма в отечественной литературе: вопросы теории. Восток 6: 110-123).

Masanov, N. E. 1995. The Nomadic Civilization of the Kazakhs. Moscow and Almaty, Kazakhstan: Gorizont and Sotsinvest. Original in Russian (Масанов Н. Э. Кочевая циивилизация казахов. Алматы - М.: Горизонт; Социнвест).

Merton, R. K. 1968. Social Theory and Social Structure. $3^{\text {rd }}$ ed. New York: Free Press.

Mirgaliev, I. M. 2014. How Old are the Golden Horde Civilization? Vestnik Kezanskogo gosudarstvennogo universiteta kultury i iskusstv 1: 118-121. Original in Russian (Миргалиев И. М. Сколько лет Золотоордынской цивилизации? Вестник Казанского государственного университета культуры и искусств 1: 118-121).

Nefedkin, A. K. 2003. The Military Affairs of the Chukchi (the Mid-SeventeenthEarly Twentieth Centuries). Saint Petersburg: Peterburgskoye vostokovedeniye. 
Original in Russian (Нефедкин А. К. Военное дело чукчей (середина XVIIначало XX в.). СПб.: Петербургское Востоковедение).

Oushakine, S. 2012. About the People of the Way: Nomadism Today. Ab Imperio, 2: 53-81. Original in Russian (Ушакин С. О людях пути: номадизм сегодня. Ab Imperio 2: 53-81).

Pauketat, T. 2007. Chiefdoms and Other Archaeological Delusions. New York etc.: AltaMira.

Perlee, Kh. 1978. Some Questions of the History of the Nomadic Civilization of Ancient Mongols. Unpublished Dr Sc. thesis. Ulanbaatar. Original in Russian (Пэрлээ Х. Некоторые вопросы истории кочевой ичивилизачии древних монголов: Автореф. дис. ... д-ра ист. наук. Улан-Батор).

Petrov, M. A. 2016. The Problems of Social and Political Organization of the Scythian Society in the Sixth-Fourth Centuries BC. Rostov/Don: South Federal University Press. Original in Russian (Петров М. А. Проблемы сочиально-политической организации скифского общества в VI-IV вв. до н. э. Ростов-на-Дону: Издательство Южного федерального университета).

Pikov, G. G. 2009. On the 'Nomadic Civilization' and about the 'Nomadic Empire'. Part 1 'Nomadic civilization.' Vestnik Novosibirskogo Universiteta, seriia: Istoriya, fililogiya 8 (1): 4-10. Original in Russian (Пиков Г. Г. О “кочевой цивилизации” и “кочевой империи”. Статья первая: “кочевая цивилизация”. Вестник НГУ, Серия: История, филология 8 (1): 4-10).

Pikov, G. G. 2010. On the 'Nomadic Civilization' and about the 'Nomadic Empire.' Part 2 'Nomadic empire' Vestnik Novosibirskogo Universiteta, seriia: Istoriya, fililogiya 9 (1): 19-32. Original in Russian (Пиков Г. Г. О “кочевой цивилизации" и “кочевой империи”. Статья вторая: “кочевая империя". Вестник НГУ, Серия: История, филология 9 (1): 19-32).

Popov, A. V. 1986. Academician B. Ya. Vladimirtsov's Theory of 'nomadic feudalism' and Current Debates on the Social Organization of the Nomads. In Kononov, A. N. (ed.), Mongolica. In Memory of Academician B. Ya. Vladimirtsova 1884-1931 (pp. 183-193). Moscow: Nauka. Original in Russian (Попов, А. В. Теория “кочевого феодализма" академика Б. Я. Владимирцова и современная дискуссия об общественном строе кочевников. В: Кононов, А. Н (ред.), Mongolica. Памяти академика Б. Я. Владимириова 1884-1931 (с. 183-189). М.: Наука).

Price, D., and Feinman, G. (eds.) 2010. Pathways to Power: New Perspectives on the Emergence of Social Inequality. New York: Springer.

Rogers, J. D. 2007. The Contingencies of State Formation in Eastern Inner Asia. Asian Perspectives 46 (2): 249-274.

Rogers, J. D. 2012. Inner Asian States and Empires: Theories and Synthesis. Journal of Archaeological Research 20 (3): 205-256.

Roth, E. A. 1996. Traditional Pastoral Strategies in a Modern World: An Example from Northern Kenya. Human Organization 55: 219-224.

Routledge, B. 2014. Archaeology and State Theory. London: Bloomsbury Academic. 
Salzman, P. C. 2002. Pastoral Nomads: Some General Observations Based on Research in Iran. Journal of Anthropological Research 58 (2): 245-264.

Salzman, P. C. 2004. Pastoralists: Equality, Hierarchy, and the State. Boulder, CO: Westview.

Scheidel W. 2010. The Xiongnu and the Comparative Study of Empire. Stanford. Available at SSRN: http://dx.doi.org/10.2139/ssrn.1663558

Scheidel, W. 2011. The Xiongnu and the Comparative Study of Empire. In Brosseder, U., and Miller, B. (eds.), Xiongnu Archaeology: Multidisciplinary Perspectives of the First Steppe Empire in Inner Asia (pp. 111-120). Bonn: Rheinische Friedrich-Wilhelms-Universitat Bonn.

Seregin, N. N. 2013. Social Organization of the Early Medieval Turks in AltaiSayan region and Central Asia. Barnaul: Altay State University Press. Original in Russian (Серегин, Н. Н. Социальная организация раннесредневековых тюрок Саяно-Алтайского региона и Центральной Азии. Барнаул: Изд-во АлтГУ).

Seregin, N. N., and Tishin, V. V. 2017. Social History of the Turks in Central Asia (the second half of the $1^{\text {st }}$ millennium AD). Part 1. Essay of the Social Structure (on the Narrative and Archaeological Sources). Barnaul: Altay State University Press. Original in Russian (Серегин, Н. Н., Тишин, В. В. Социальная история тюрков Центральной Азии (вторая половина I тыс. н.э.). Часть 1: Очерки социальной структуры (по письменным и археологическим источникам). Барнаул: Изд-во АлтГУ).

Shiraishi, N. 2001. Chingisy Kan no kōkogaku [Archaeology of Genghis Khan]. Tōkyō: Dōseisha.

Shiraishi, N. 2002. Mongoru teikokushi no kōkogakuteki kenkyū [Archaeological Researches on the History of the Mongol Empire]. Tōkyō: Dōseisha.

Shiraishi, N. 2015. The Study of the Process of the Origins of Mongolian Empire from the Viewpoint of Social Evolution. Srednevekovye drevnosti Primorya 3: 422-428. Original in Russian (Шираиси Н. Исследование процесса образования монгольской империи с точки зрения социальной эволюции. Средневековые древности Приморья 3: 422-428).

Skrynnikova, T. D. 1997. Charisma and Power during the Epoch of Chinggis Khan. Moscow: Vostochnaya literatura. Original in Russian (Скрынникова Т. Д. Харизма и власть в эпоху Чингис-хана. М.: Восточная литература).

Smith, M. 2011. Empirical Urban Theory for Archaeologists. Journal of Archaeological Method and Theory 18:167-192.

Sneath, D. 2007. The Headless State: Aristocratic Orders, Kinship Society, and the Misrepresentation of Nomadic Inner Asia. New York: Columbia University Press.

Sneath, D. 2009. Tribe, Ethnos, Nation: Rethinking Evolutionist Social Theory and Representations of Nomadic Inner Asia. Ab Imperio 4: 80-110.

Sneath, D. 2013. Ayimag, Uymaq and Baylik: Re-examining Notions of the Nomadic Tribe and State. In Paul, J. (ed.), Nomad Aristocrats in a World of Empire (pp. 161-186). Wiesbaden: Steiner Verlag. 
Sodnompilova, M. M. 2005. The Semantics of Traditional Dwelling of Buryats. Irkutsk: MION. Original in Russian (Содномпилова, М. М. Семантика традиционного жилища бурят. Иркутск: МИОН).

Spencer, P. 1973. Nomads in Alliance: Symbiosis and Growth Among the Rendille and Samburu of Kenya. London, UK: Oxford University Press.

Tamura J. 1956. 北アジア世界における國家の類型 [Types of Nations in the World of North Asia]. Memoirs of the Faculty of Letters, Kyoto University 4: 475-492.

Tishin, V. V. 2015. Historiography of the Social History of Turk Khaganate, $6^{\text {th }}$ $8^{\text {th }}$ centuries. Unpublished PhD Thesis. Moscow, Institute for Oriental Studies RAS, World History. Original in Russian (Тишин В. В. Историография социиальной истории тюркского каганата VI-VIII вв. Дисс. ... канд. ист. наук. М.).

Togan, I. 1998. Flexibility and Limitation in Steppe Formations: the Kerait Khanate and Chinggis Khan. Leiden, etc.: Brill.

Trepavlov, V. V. 1993. State Structure of Mongolian Empire in the $13^{\text {th }}$ Century: The Problem of Historical Succession. Moscow: Nauka. Original in Russian (Трепавлов В. В. Государственный строй Монгольской империи XIII в.: Проблема исторической преемственности. М.: Наука).

Turchin, P. 2009. A Theory for Formation of Large Empires. Journal of Global History 4: 191-217.

Vasyutin, S. A. 2003. Typology of the Pre-State and Statehood Systems of Nomads. In Kradin, N. N., Bondarenko, D. M., and Barfield, T. (eds.), Nomadic Pathways in Social Evolution (pp. 50-62). Moscow: Center for Civilizational and Regional Studies of the Russian Academy of Sciences.

Vasyutin, S. A. 2010. Nomadic Empires of Central Asia: Unfinished Dispute. Vestnik Novosibirskogo Universiteta, seriya: Istoriya, fililogiya 9 (1): 33-40. Original in Russian (Васютин С. А. Кочевые империи Центральной Азии: неоконченный диспут. Вестник НГУ, Серия: История, филология 9 (1): 33-40).

Vasyutin, S. A. 2011a. Anthropology of Supreme Power in Nomadic Empires. Sredniye Veka 72 (1-2): 306-329. Original in Russian (Васютин С. А. Антропология верховной власти в кочевых империях. Средние века 72 (1-2): 306-329).

Vasyutin, S. A. 2011b. To the Question of the Interaction of the First Turk Khaganate and China in the Context of 'Bipolar World' Concept by T. Barfield. Vestnik Novosibirskogo Universiteta, seriia: Istoriya, fililogiya 10 (1): 34-39. Original in Russian (Васютин С. А. К вопросу о взаимодействии Первого Тюркского каганата и Китая в свете концепции «биполярного мира» Т. Барфилда. Вестник НГУ, сер. История, филология 10 (1): 34-39).

Vasyutin, S. A. 2015. The Model of the Political Transformation of the Da Liao as an Alternative to the Evolution of the Structures of Authority in the Early Medieval Pastoral Empires of Mongolia. In Bemmann, J., and Schmauder, M. (eds.), Complexity of Interaction along the Eurasian Steppe Zone in the First Millennium CE (pp. 391-435). Bonn: University of Bonn. 
Vasyutin, S. A. 2017. Power and Society in Nomadic Empires of Central Asia, the $6^{\text {th }}$ - beginning of the $12^{\text {th }}$ centuries. Unpublished Dr. Habil. Ulan-Ude. Original in Russian (Васютин С. А. Власть и сочиум в кочевых империях Центральной Азии VI-начала XII в.: Дисс. ...д-ра ист. наук. Улан-Удэ).

Vasyutin, S. A., and Dashkovsky, P. K. 2009. Social and Political Organization of the Nomads in Late Antiquity and Early Middle Age: Russian Historiography and Contemporary Problematics. Barnaul: Altay State University Press. Original in Russian (Васютин, С. А., Дашковский П. К. Социально-политическая организачия кочевников поздней древности и раннего средневековья (отечественная историография и современные проблемы). Барнаул: Издательство Алтайского государственного Университета).

Vdovchenkov, E. V. 2016. Power Organization in the Sarmatian Society. In Popov, V. A. (ed.), The Early Forms of Potestarian Organization (pp. 107-129). Saint Petersburg: Saint Petersburg Scientific Centre Press. Original in Russian (Вдовченков Е. В. Потестарная организация сарматского общества. Попов, В. А. (ред.), Ранние формы потестарной организации (с. 107-129). СПб.: СПбНЦ РАН).

Vdovchenkov, E. V. 2018. The Social History of the Sarmatians in Lower Don River Basin. Moscow: Akvilon. Original in Russian (Вдовченков Е. В. Социальная история сарматов Нижнего Подонья. М.: Аквилон).

Wason, P. 1995. Social Types and the Limits of Typological Thinking in Social Archaeology. In Kradin, N. N., and Lynsha, V. A. (eds.), Alternative Pathways to Early State (pp. 19-27). Vladivostok: Dalnauka.

Wittfogel, K. A. 1957. Oriental Despotism. A Comparative Study of Total Power. New Haven: Yale University Press.

Wright, D. 1995. Wealth and War in Sino-Nomadic Relations. The Tsing Hua Journal of Chinese Studies 25 (3): 295-308.

Wright, J. 2017. The Honest Labour of Stone Mounds: Monuments of Bronze and Iron Age Mongolia as Costly Signals. World Archaeology 49 (4): 547-567.

Yoffee, N. 2005. Myth of the Archaic State: Evolution of the Earliest Cities, States, and Civilizations. Cambridge: Cambridge University Press.

Zheleznyakov, A. S. 2016. Mongolian Civilization: History and Present Times. Moscow: Ves Mir. Original in Russian (Железняков А. С. Монгольская иивилизация. История и современность. М.: Весь мир).

Zhukovskaya, N. L. 1984. Categories and Symbols of Traditional Mongolian Culture. Moscow: Nauka. Original in Russian (Жуковская, Н. Л. Категории и символика традиционной культуры монголов. М.: Наука). 